\title{
Studi Eksplorasi Perkuliahan Perkembangan Embrio Mamalia Matakuliah Struktur Perkembangan Hewan II
}

\author{
Ardiyas Robi Saputra ${ }^{1}$, Mohamad Amin ${ }^{1}$, Umie Lestari ${ }^{1}$ \\ ${ }^{1}$ Pendidikan Biologi-Universitas Negeri Malang
}

\section{INFO ARTIKEL \\ Riwayat Artikel:}

Diterima: 29-04-2019

Disetujui: 23-09-2020

\section{Kata kunci:}

exploratory studies, mammalian embryonic development; structure of animal development studi eksplorasi; perkembangan embrio mamalia; struktur perkembangan hewan

\author{
Alamat Korespondensi: \\ Ardiyas Robi Saputra \\ Pendidikan Biologi \\ Universitas Negeri Malang \\ Jalan Semarang 5 Malang \\ E-mail: ardiyasrobisaputra@gmail.com
}

\begin{abstract}
ABSTRAK
Abstract: This study aims to determine the teaching material requirements that will be developed in the topic of mammalian embryo development in SPH II course. This data collection of research uses questionnaire sheets to students and lecturer. The difficulties experienced by students during the SPH II lecture included the complexity of the topic and learning resources. Students assessed the teaching materials need to be develop and interested to use teaching material based on research. The conclusion of this study is necessary to develop module as teaching materials based on research results so that students can learn independently through intact material.
\end{abstract}

\begin{abstract}
Abstrak: Penelitian ini bertujuan untuk mengetahui kebutuhan bahan ajar yang dikembangkan pada materi perkembangan embrio mammalia matakuliah Struktur Perkembangan Hewan II. Pengumpulan data peneltian ini dengan menggunakan lembar kuesioner kepada mahasiswa dan dosen. Hasil penelitian menunjukkan kesulitan yang dialami oleh mahasiswa selama mengikuti perkuliahan Struktur Perkembangan Hewan II diantaranya karena kompleksitas materi dan sumber belajar. Mahasiswa menilai perlu dikembangkan bahan ajar tambahan dan tertarik menggunakan bahan ajar berbasis hasil penelitian. Kesimpulan penelitian ini adalah perlu dikembangkan bahan ajar berbasis hasil penelitian berupa modul agar mahasiswa dapat belajar mandiri dengan materi yang utuh.
\end{abstract}

Pendidikan bertujuan untuk membuat peserta didik dapat mengembangkan potensi dirinya melalui proses pembelajaran (UndangUndang Republik Indonesia Nomor 20 Tahun 2003). Mencerdaskan kehidupan bangsa dan kemajuan ilmu pengetahuan dan teknologi merupakan peran penting dari pendidikan tinggi dalam peningkatan daya saing bangsa dan menghasilkan lulusan yang menguasai ilmu pengetahuan (Undang-Undang Republik Indonesia Nomor 12 Tahun 2012) sehingga kurikulum pendidikan tinggi disusun berdasarkan Kerangka Kualifikasi Nasional Indonesia (KKNI) (Peraturan Presiden Republik Indonesia Nomor 8 Tahun 2012). Strata-1 dikelompokkan dalam level 6 KKNI yang dituntut memiliki keterampilan umum diantaranya mampu menerapkan pemikiran logis, kritis, sistematis dan inovatif (Direktorat Jenderal Pendidikan Tinggi, 2014). Capaian pembelajaran lulusan sebagai deskripsi kualifikasi KKNI yang telah disusun tidak hanya memberikan manfaat bagi mahasiswa untuk memahami konsep keilmuan saja, namun juga dapat menjadi ilmu terapan dan membeikan manfaat praktis.

Struktur perkembangan hewan II adalah matakuliah lanjutan dari Struktur Perkembangan Hewan I yang berperan sebagai dasar bidang ilmu hewan. Pada matakuliah ini, secara umum mempelajari struktur makroanatomi dan mikroanatomi organ, ontogeni organ dan perkembangan mulai dari gametogenesis sampai dengan terbentuknya individu baru. Pembahasan pada matakuliah ini meliputi struktur histologis jaringan dasar dan jaringan khusus yang menyusun suatu organ tubuh hewan dan mampu menjelaskan struktur-anatomi serta proses pembentukan perkembangan berbagai sistem organ pada vertebrata (RPS SPH II, 2018).

Bahan ajar merupakan kumpulan konten terorganisasi yang disajikan bersama yang digunakan untuk mendeskripsikan sumber daya yang digunakan untuk menyampaikan instruksi membantu guru (Direktorat Tenaga Kependidikan, 2008; Amri, 2010), perencanaan dan penelaahan implementasi pembelajaran (Majid, 2008), berisikan materi pembelajaran, metode, batasanbatasan, dan cara mengevaluasi dalam mencapai tujuan yang diharapkan (Widodo \& Jasmadi, 2008). Dosen pengampu matakuliah Struktur Perkembangan Hewan II menilai perkembangan embrio mammalia termasuk materi yang sulit karena materi tersebut bersifat abstrak dan kompleks. Bahan ajar pada matakuliah ini perlu ditingkatkan lagi sesuai perkembangan ilmu pengetahuan. 


\section{METODE}

Jenis penelitian ini adalah deskriptif pada matakuliah Struktur Perkembangan Hewan II Program Studi S-1 Pendidikan Biologi FMIPA Universitas Negeri Malang. Objek penelitian ini perkuliahan embrio mammalia yang berjumlah 35 orang mahasiswa yang ditetapkan secara purposive random sampling. Waktu penelitian dilakukan pada bulan Oktober-November 2018. Teknik pengumpulan data dilakukan dengan menggunakan lembar observasi dan kuesioner dengan 22 pertanyaan dan meminta mahasiswa memberikan alasan terhadap jawaban angket. Tahap ini mengikuti fase investigasi awal dari rancangan pengembangan PLOMP yang terdiri dari analisis kurikulum, analisis materi, dan analisis sumber belajar.

\section{HASIL}

Hasil analisis kebutuhan terhadap matakuliah Struktur Perkembangan Hewan II terdiri dari analisis kurikulum, materi, dan sumber belajar. Hasil analisis terangkum pada tabel 1 .

Tabel 1. Hasil Analisis Kebutuhan Pengembangan Bahan Ajar

\begin{tabular}{|c|c|c|c|}
\hline No. & Aspek & Hasil & Keterangan \\
\hline 1 & Kegiatan Perkuliahan & 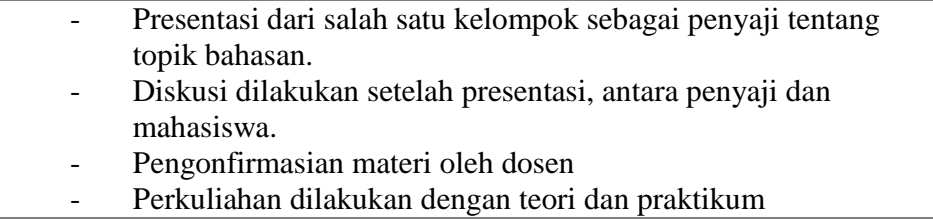 & \\
\hline 2 & Kurikulum & 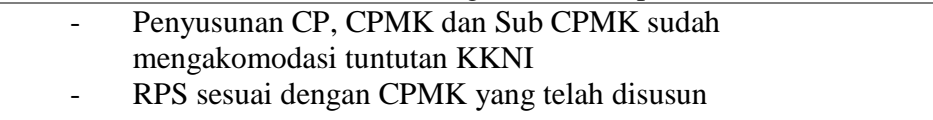 & \\
\hline 3 & Materi Perkuliahan & $\begin{array}{l}\text { Materi perkembangan embrio mammalia diajarkan pada } \\
\text { pertemuan ke-9. } \\
\text { - } \quad \text { Materi kompleks dan saling berhubungan/berkesinambungan. } \\
\text { - } \quad \text { Materi dibahas secara mandiri oleh mahasiswa melalui diskusi. } \\
\text { - } \quad \text { Dosen memberikan penguatan ketika ada materi yang belum } \\
\text { terjawab. }\end{array}$ & \\
\hline 4 & Sumber Belajar & $\begin{array}{ll}\text { - } & \text { Artikel } \\
\text { - } & \text { E-book (Gilbert, 2010) } \\
\text { - } & \text { Buku ajar karangan tim dosen Struktur Perkembangan Hewan } \\
& \text { II } \\
\text { - } & \text { Petunjuk Praktikum } \\
\text { - } \quad \text { Sajian materi pada buku ajar lebih sederhana namun tidak } \\
\text { terdapat materi tentang determinasi kelamin yang seharusnya } \\
\text { disajikan karena berhubungan dengan diferensiasi dan } \\
\text { organogenesis serta tidak disebutkan secara rinci gen yang } \\
\text { berperan dalam pembentukan gonad } \\
\text { Materi dalam } e \text {-book sulit untuk dipahami karena lebih } \\
\text { kompleks dan rumit }\end{array}$ & \\
\hline 6 & $\begin{array}{l}\text { Pemahaman topik } \\
\text { perkembangan embrio } \\
\text { mammalia }\end{array}$ & $\begin{array}{l}\text { Sulit } \\
\text { Tidak sulit }\end{array}$ & $\begin{array}{l}83,67 \% \\
23,33 \%\end{array}$ \\
\hline 7 & $\begin{array}{l}\text { Kesulitan selama } \\
\text { perkuliahan }\end{array}$ & $\begin{array}{l}\text { Kompleksitas materi } \\
\text { Sumber belajar }\end{array}$ & $\begin{array}{l}56,67 \% \\
43,33 \%\end{array}$ \\
\hline 8 & $\begin{array}{l}\text { Perlu bahan ajar } \\
\text { tambahan }\end{array}$ & $\begin{array}{l}\text { Perlu } \\
\text { Tidak }\end{array}$ & $\begin{array}{l}63,33 \% \\
36,67 \%\end{array}$ \\
\hline 9 & $\begin{array}{l}\text { Penggunaan bahan ajar } \\
\text { berbasis penelitian }\end{array}$ & $\begin{array}{l}\text { Pernah } \\
\text { Tidak pernah }\end{array}$ & $\begin{array}{l}0 \\
100 \%\end{array}$ \\
\hline 10 & $\begin{array}{l}\text { Tertarik menggunakan } \\
\text { bahan ajar berbasis } \\
\text { penelitian }\end{array}$ & $\begin{array}{l}\text { Iya } \\
\text { Tidak }\end{array}$ & $\begin{array}{l}73,33 \% \\
26,67 \%\end{array}$ \\
\hline
\end{tabular}


Hasil analisis kurikulum pada matakuliah Struktur Perkembangan Hewan II diperoleh CP, CPMK, dan Sub CPMK sudah mengakomodasi tuntutan KKNI yang tercantum dalam Rencana Perkuliahan Semester. Materi yang tercantum dalam RPS terdiri dari tujuh materi besar, yaitu gametogenesis, fertilisasi, perkembangan embrio, pembentukan selaput ekstra embrio, organogenesis, kelainan perkembangan, dan rergenerasi. Seluruh materi tersebut saling berhubungan/berkesinambungan satu sama lain. Berdasarkan analisis materi diketahui mahasiswa menilai materi perkembangan embrio mammalia dikategorikan sulit. Kesulitan lain mahasiswa dalam memahami materi disebabkan oleh sumber belajar dan komplesitas materi.

Hasil analisis terhadap $e$-book yang digunakan pada materi perkembangan embrio disebabkan oleh sajian materi yang rumit dan proses determinasi kelamin disajikan dalam chapter yang berbeda sehingga terpisah dengan mekanisme perkembangannya. Analisis terhadap buku ajar karangan tim dosen pengampu matakuliah dinilai materi yang disajikan sudah lebih sederhana jika dibandingkan dengan e-book, namun masih terdapat konsep yang belum disajikan seperti determinasi kelamin. Proses determinasi kelamin pada buku ajar ini dimuat di dalam sub materi pembentukan gonad yang menjelaskan pada awalnya gonad bersifat bipotensial yang memiliki potensi untuk berkembang menjadi testis atau ovarium. Proses ini diatur oleh genotip namun tidak menjelaskan genotip apa yang berperan dan bagaimana mekanismenya.

\section{PEMBAHASAN}

Berdasarkan hasil yang diperoleh, mahasiswa kesulitan dalam memahami materi perkuliahan Struktur Perkembangan Hewan II. Kesulitan tersebut diakibatkan oleh kompleksitas materi $(56,67 \%)$ dan sumber belajar $(43,33 \%)$. Hal ini sesuai dengan penelitian yang dilakukan oleh (Dewantara, 2012) dan (Amerudin, 2013) yang menyatakan bahwa kesulitan yang dialami mahasiswa dapat diakibatkan oleh beberapa faktor diantaranya kebiasaan belajar, metode, media, tingkat kompleksitas materi, dan bahan ajar.

Bahan ajar perlu untuk dikembangkan dengan alasan ketersediaan bahan sesuai tuntutan kurikulum, karakteristik sasaran, dan tuntunan pemecahan masalah belajar (Direktorat Tenaga Kependidikan, 2008). Pengembangan bahan ajar yang sesuai dengan perkembangan ilmu pengetahuan salah satunya dengan cara memanfaatkan hasil penelitian. Hasil penelitian merupakan contoh aplikatif yang digunakan untuk memperluas dan memperdalam materi karena memberikan pengalaman nyata karena informasi yang disajikan berasal dari pengamatan (Primiani, 2014).

Analisis terhadap masalah yang telah dilakukan maka perlu dikembangkan adalah bahan ajar tambahan yang memuat materi perkembangan embrio dengan lebih sederhana namun dibahas secara detail dan utuh dengan memanfaatkan hasil penelitian. sehingga bahan ajar yang dipilih untuk dikembangkan adalah modul. Modul merupakan bahan ajar yang memiliki karakteristik selfcontained yang menyajikan materi secara utuh dan adaptive yang memiliki daya adaptasi tinggi terhadap perkembangan ilmu dan teknologi (Direktorat Tenaga Kependidikan, 2008; Prastowo, 2011; Rahdiyanta, 2015). Pengembangan modul yang memanfaatkan hasil penelitian akan dapat menghubungkan antara fakta dan konsep dalam materi pembelajaran (Parmin \& Peniati, 2012).

Berdasarkan hasil observasi pembelajaran pada matakuliah Struktur Perkembangan Hewan II, mahasiswa melakukan presentasi materi perkembangan embrio mammalia dan organogenesis, namun belum membahas peran gen dalam determinasi. Determinasi adalah tahap yang akan menentukan perkembangan embrio nantinya akan menjadi individu jantan atau betina karena pada awalnya gonad disebut genital ridge yang terbentuk oleh proliferasi epitel dan kondensasi lapisan mesenkim (Sadler, 2012).Gen SRY bertanggung jawab dalam determinasi kelamin jantan yang menginisiasi perkembangan testis selama embriogenesis pada mammalia ((Berta et al., 1990; Koopman et al., 1990; Sinclair et al.,1990; Koopman et al.,1991; Su \& Lau, 1993; Sekido \& Lovell-Badge, 2009; Kashimada \& Koopman, 2010; Snustad \& Simmons, 2012).

Pengembangan modul menyesuaikan dengan pendekatan konstruktivistik yang lebih menekankan pada peran aktif mahasiswa dalam membentuk pengetahuan (Nurhasnawati, 2011), belajar melalui penemuan, menyusun konsep dan memberi makna tentang hal yang dipelajari (Sumarsih, 2019). Pembelajaran konstruktivistik mengakibatkan guru lebih banyak bertanya dan memberi kesempatan kepada siswa untuk menyatakan apa yang diketahui dan tidak diketahuinya (Utami et al., 2009). Salah satu model pembelajaran konstruktivistik adalah model pembelajaran inkuiri. Pembelajaran inkuiri merupakan suatu rangkaian belajar yang memberikan kesempatan pada siswa untuk terlibat aktif dalam menemukan fakta (Suryosubtoro, 2009; Wulandari \& Sidoarjo, 2016), mencari dan menyelidiki secara kritis sehingga mereka dapat merumuskan sendiri penemuan (Trianto, 2007), dan mampu memecahkan masalah yang dihadapi (Amri \& Ahmadi, 2010).

\section{SIMPULAN}

Perlu dikembangkan bahan ajar yang mampu mengatasi permasalahan dalam pembelajaran yang memuat materi lebih sederhana namun dibahas secara detail dan utuh sehingga lebih mudah dipahami. Bahan ajar yang dikembangkan adalah modul berbasis inkuiri berdasarkan hasil penelitian sebagai contoh aplikatif sesuai dengan perkembangan ilmu pengetahuan. Pengembangan modul ini dilakukan dengan melanjutkan rancangan pengembangan PLOMP. 


\section{DAFTAR RUJUKAN}

Amri, S., \& Ahmadi, K.I. (2010). Proses Pembelajaran Kreatif dan Inovatif Dalam Kelas. Jakarta: Prestasi Pustaka Raya. Amerudin., Ariyati, E., \& Nurdini, A. (2013). Deskripsikan Kesulitan Belajar dan Faktor Penyebabnya Pada Materi Fungi di SMA Islam Bawari Pontianak dan Upaya Perbaikannya. Jurnal Pendidikan dan Pembelajaran Khatulistiwa, 2(9), 1-11.

Berta, P., Hawkins, J. B., Sinclair, A. H., Taylor, A., Griffiths, B. L., Goodfellow, P. N., \& Fellous, M. (1990). Genetic Evidence Equating SRY and the Testis-Determining Factor. Nature, 348(6300), 448-450. https://doi.org/10.1038/348448a0

Dewantara, I. P. M. A. S. (2012). Identifikasi Faktor Penyebab Kesulitan Belajar Keterampilan Berbicara Siswa Kelas VIII-E SMPN 5 Negara dan Strategi Guru untuk Mengatasinya. Jurnal Pendidikan dan Pembelajaran Bahasa Indonesia, 1(2), $1-15$.

Direktorat Jenderal Pendidikan Tinggi. (2014). Panduan Penyusunan Capaian Pembelajaran Lulusan Program Studi. Kementerian Pendidikan dan Kebudayaan.

Direktorat Tenaga Kependidikan. (2008). Penulisan Modul. Departemen Pendidikan Nasional.

Kashimada, K., \& Koopman, P. (2010). Sry: The Master Switch in Mammalian Sex Determination. Development (Cambridge, England), 137(23), 3921-3930. https://doi.org/10.1242/dev.048983

Koopman, P., Gubbay, J., Vivian, N., Goodfellow, P., \& Lovell-Badge, R. (1991). Male Development of Chromosomally Female Mice Transgenic for Sry. Nature, 351, 117-121.

Koopman, P., Munsterberg, A., Capel, B., Vivian, N., \& Lovell-Badge, R. (1990). Expression of a Candidate Sex-Determining Gene During Mouse Testis Differentiation. Nature, 348, 450-452.

Nurhasnawati. (2011). Model-Model Pembelajaran Konstrutivisme. Anida, 36(2), 237-259.

Parmin., \& Peniati, E. (2012). Pengembangan Modul Matakuliah Strategi Belajar Mengajar IPA Berbasis Hasil Penelitian Pembelajaran. Jurnal Pendidikan IPA Indonesia, 1(1), 8-15.

Peraturan Presiden Republik Indonesia Nomor 8 Tahun 2012. (2012). Peraturan Presiden Republik Indonesia Nomor 8 Tahun 2012.

Primiani, C. N. (2014). Pengembangan Buku Ajar Berbasis Penelitian Bahan Alam Lokal sebagai Estrogenik pada Matakuliah Fisiologi Hewan. Prosiding Mathematics and Sciences, 407-4010.

Rahdiyanta, D. (2015). Bimbingan Teknis Program Sarjana Mengajar untuk Pemenuhan Guru Produktif SMK: Materi Teknik Penyusunan Modul. Universitas Negeri Yogyakarta.

Sadler, T. (2012). Medical Embryology (12th ed.). Philadelphia United State of America: Lippincott William \& Wilkins.

Sekido, R., \& Lovell-Badge, R. (2009). Sex Determination and SRY: Down to a Wink and a Nudge? Trends in Genetics, 25(1), 19-29. https://doi.org/10.1016/j.tig.2008.10.008

Sinclair, A. H., \& Philippe Berta, Mark S. Palmer, J. Ross Hawkins, Beatrice L. Griffiths, Matthijs J. Smith, Jamie W. Foster, Anna-Maria Frischauf, R. L.-B. \& P. N. G. (1990). A Gene from the Human Sex-Determining Region Encodes a Protein with Homology to a Conserved DNA-Binding Motif. NATURE, 346, 240-244.

Snustad, D. P., \& Simmons, M. J. (2012). Principles of Genetics. In Control (6th ed.). https://doi.org/10.1016/B978-1-85617803-7.50022-5

Su, H., \& Lau, Y. F. (1993). Identification of The Transcriptional Unit, Structural Organization, and Promoter Sequence of the Human Sex-Determining Region Y (SRY) Gene, Using a Reverse Genetic Approach. American Journal of Human Genetics, 52(1), 24-38.

Sumarsih, S. (2019). Implementasi Teori Pembelajaran Konstruktivistik Dalam Pembelajaran Matakuliah Dasar-Dasar Bisnis. Jurnal Pendidikan Akuntansi Indonesia, 8(1), 54-62. https://doi.org/10.21831/jpai.v8i1.945

Undang-Undang Republik Indonesia Nomor 12 Tahun 2012. (2012). Undang-Undang Republik Indoenesia.

Undang-Undang Republik Indonesia Nomor 20 Tahun 2003. (2003). Undang-Undang Republik Indoenesia.

Utami, B., Iskandar, S. M., \& Ibnu, S. (2009). Penerapan Pembelajaran Konstruktivisme Dalam Pembelajaran. Prosiding Seminar Nasional Kimia dan Pendidikan Kimia, 1(January 2009), 14-209.

Wulandari, F., \& Sidoarjo, U. M. (2016). Penerapan Model Pembelajaran Inkuiri Terbimbing. Pedagogia, 5(2), $267-278$. 